FACTA UNIVERSITATIS

Series: Physical Education and Sport, Vol. 16, No 4, 2018, pp. 739 - 747

https://doi.org/10.22190/FUPES181106065M

Research article

\title{
DIFFERENCES IN AGILITY AND EXPLOSIVE POWER OF BASKETBALL PLAYERS IN RELATION TO THEIR POSITIONS ON THE TEAM
}

\author{
UDC 796.323 \\ 796.012.112.23
}

\begin{abstract}
Milan Mitić, Miloš Paunović, Mladen Živković, Nikola Stojanović, Ivana Bojić, Miodrag Kocić
\end{abstract}

Faculty of Sport and Physical Education, University of Niš, Niš, Serbia

\begin{abstract}
Basketball is a sports game which consists of rapid changes in direction of movement, sudden stopping and starting for driving and dribbling and a great number of jumps. The various positions on a basketball team precisely determine the requirements for specific forms of movement, even though contemporary basketball strives for all players in all positions to possess the aforementioned abilities. A sample of 15 male basketball players, divided into three groups of five players each, based on their positions on the team, including the guard, forward and center position, was used to determine differences in agility (Agility T Test, Hexagon Agility Test, Illinois Agility Test u Lane Agility Drill) and explosive power (the Squat jump, Countermovement Jump, Drop Jump and One-legged Counter Movement Jump). To determine the differences between the basketball players in relation to their positions on the team, the ANOVA analysis for independent samples was used as was a post-hoc analysis. The research results have indicated that there is a difference between the guard position compared to the forward and center position.
\end{abstract}

Key words: male basketball players, agility, explosive power, playing position, differences

Received November 6, 2018 / Accepted January 6, 2019

Corresponding author: Milan Mitić

University of Niš, Faculty of Sport and Physical Education, Čarnojevića 10a, 18000 Niš, Serbia

Phone: +381 18510900 •E-mail: milanmitic26@gmail.com 


\section{INTRODUCTION}

Basketball is an anaerobic-aerobic sports game (Delextrat \& Cohen, 2009), and as such it requires activities of high intensity such as jumps, sprints, rapid changes in direction (with stopping) of movement and low-intensity activities such as walking (with stopping). Achieving top sports results in basketball is conditioned by the proper selection of players in relation to their predispositions (Popović, Smajić, Molnar, \& Mašanović, 2009). Kocić, Berić, Radovanović, \& Simović (2012) emphasized the high quality of work in basketball schools in Serbia, starting at the earliest age, because the learnt structures of the movements are qualitatively at the same level at different competition ranks. Recently, the principles of the athlete preparation process, which is aimed at the acquisition of sports form, have begun to differ from existing ones (Issurin, 2008). Previously, the dominant opinion was that athletes needed to be involved only in their sport of choice in order to develop the needed skills, i.e. the field they were otherwise actively involved in. However, with the development of basketball and the increase in the requirements of competitions, training has begun to focus more on the development of physical predispositions (Trunić, 2007). Thus more recently, agility training and explosive power training have both become a special focus of study of numerous researchers (Jamurtas et al., 2000; Kremer \& Gomez, 2010; Asadi \& Arazi, 2012; Zhang, 2013; Lehnert, Hůlka, Malý, Fohler \& Zahálka, 2014; Morsal et al., 2014; Nikolić, 2016; Stojanović, et al., 2018). Agility is an ability which is of special importance for players in all positions on a team. Precisely for this reason most coaches and experts in the field of basketball favor a rapid transition in offence and defense. Basketball is a game meant for players of above average height, so special attention should be paid to the speed in rapid change in movement during training, as well as to explosive power (Jakovljević, Karalejić, Pajić, \& Mandić, 2011), primarily because activities of this type frequently occur during a game. Anthropometric features have a significant influence on the development of agility (Ademović, Milenković, Pavlović, \& Kocić, 2014). Agility is an ability which is influenced by speed and power and is also dependent on the quality of the leg muscles (Young, Dawson, \& Henry, 2015), while it is also of great significance for the successful basketball play (Ostojić, Mazić, \& Dikić, 2006; Delextrat \& Cohen, 2009; Metaxas, Koutlianos, Sendelides, \& Mandroukas, 2009). Furthermore, Scanlan, Humphries, Tucker, \& Dalbo (2014) determined that cognitive abilities have a great influence on the reactive agility of the basketball players. A basketball player performs up to 100 different jumps during a game (Manojlović \& Erčulj, 2013), which indicates the special importance of the explosive power relevant to the type of jump. Explosive power in basketball is important for all positions, primarily because of the individual tasks placed before each player. The guard position players should primarily possess the ability to manifest speed-power features in all their forms during offence, due to its organization (the rapid and safe driving of the ball from the defensive to the offensive half of the court) and during defense due to the set tasks related to the opponents. Point forwards and centers should be in possession of the ability to in a timely fashion block and jump to obtain the balls which have bounced off the basket. During offence, through timely demarcation and positioning they are tasked with obtaining possession of the ball closer to the basket, jumping in offence and blocking (Kocić, 2007). Of the overall number of shots at the basket, approximately $45 \%$ are unsuccessful, of which approximately $35 \%$ of 
the balls will be caught during an offensive jump (Trninić, 1996, in Ademović, 2016). For all the aforementioned actions, explosive power is responsible.

The aim of this research was to determine the differences in the motor skills of agility and explosive power between basketball players in relation to their positions on the team.

\section{METHODS}

The sample of participants was made up of 15 male basketball players from the O.K.K. "Konstantin" (Niš) that will compete in the Second National League of Serbia in the 2018/19 season. The participants were divided into three groups (point forward, back, center). The participants, experts in the field of sport, and club management were made familiar with the means and testing guidelines, and permission was obtained from the club management for the data obtained during the course of the testing to be used for scientific research.

\section{The measuring instruments}

To evaluate agility, four tests were used: Agility T Test, Hexagon Agility Test, Illinois Agility Test and Lane Agility Drill (Getchell, 1979; Pauole, Madole, Garhammer, Lacourse, \& Rozenek, 2000; Sigmon, 2005; Beekhuizen, Davis, Kolber, \& Cheng, 2009). To evaluate explosive power of the lower extremities, the following tests were used: Squat Jump, Countermovement Jump, Drop Jump and One-legged (OL) Counter Movement Jump (Bosco, Luhtanen, \& Komi, 1983). To measure explosive power of the of vertical jump type, the "Optojump" equipment was used (Microgate, Italy).

\section{Statistical data analyses}

The data analysis was carried out using the SPSS program for statistical analysis. For all the obtained data, the following was calculated: the basic central and dispersion parameters (Mean, Skewness, Kurtosis, Range, Min, Max, and SD). To determine the differences in agility and explosive power among the basketball players in relation to their positions on the team, the ANOVA for independent samples was used (the statistical level of significance was set at $\mathrm{p}<0.05$ ) and a post-hoc analysis.

\section{RESULTS}

Table 1 The univariate analysis of variance of agility in relation to the basketball players' various positions

\begin{tabular}{lccccc}
\hline Agility Tests & Mean ( Back) & Mean (Point forward) & Mean (Center) & F & P-level \\
\hline T-test (in s) & 9.76 & 10.24 & 10.30 & 2.13 & .161 \\
Hexagon (in s) & 11.88 & 12.30 & 12.40 & 0.39 & .683 \\
Illinois (in s) & 16.26 & 17.24 & 17.70 & 5.12 & $\mathbf{. 0 2 5}^{*}$ \\
Lane Drill (in s) & 13.76 & 13.92 & 13.80 & 0.06 & .943 \\
\hline
\end{tabular}


The univariate analysis of variance of agility (Table 1) determined, based on the coefficient of the F-variable and the significance (P-level), that a statistically significant difference exists only for the Illinois test (.025). The remaining tests do not indicate any differences in the agility of the basketball players in relation to their position on the team.

Table 2 Post hoc Fisher LSD test

\begin{tabular}{lccc}
\hline Illinois & $\{1\}$ & $\{2\}$ & $\{3\}$ \\
& 16.26 & 17.24 & 17.70 \\
\hline 1 - Guard & & .054 & $\mathbf{. 0 0 9}$ \\
2 - Point forward & .054 & & .337 \\
3 - Center & $\mathbf{. 0 0 9}$ & .337 & \\
\hline
\end{tabular}

In Table 2, the statistically significant difference can be noted between the guard and center positions (.009). The difference between the guard and point forward positions is very close to the level of statistical significance (.054).

Table 3 The univariate analysis of variance for explosive power in relation to basketball players' various positions

\begin{tabular}{lccccc}
\hline Expl. Power Tests & Mean (Back) & Mean (Point forward) & Mean (Center) & F & P-level \\
\hline SJ (in cm) & 35.90 & 33.16 & 26.84 & 5.54 & $\mathbf{. 0 2 0}^{*}$ \\
CMJ (in cm) & 37.80 & 35.44 & 31.06 & 4.01 & $\mathbf{. 0 4 6}^{*}$ \\
DJ (in cm) & 46.34 & 43.02 & 38.82 & 3.24 & .075 \\
OL CMJ (in cm) & 21.80 & 18.32 & 16.58 & 8.03 & $\mathbf{. 0 0 6}^{* *}$ \\
\hline
\end{tabular}

The univariate analysis of variance for explosive power (Table 3) indicated that based on the F-variable and the level of significance (P-level) a statistically significant difference was determined for the tests the Squat Jump (SJ .020), Countermovement Jump (CMJ .046) and One-legged Countermovement Jump (OL CMJ .006).

In Table 4 the statistically significant difference can be noted between the guard and center positions (.007); (.016); (.002), guard and point forward positions (.022) and point forward and center positions (.043). The Drop Jump test (DJ .075) showed no indication of a statistically significant difference after the analysis of variance; however, since the results were close to the selected level of significance, a post-hoc test was performed and it was determined that there is a statistically significant difference between the guard and center position (.026) which was still not great enough to influence the existence of an overall significance between all three groups. 
Table 4 Post hoc Fisher LSD test

\begin{tabular}{lccc}
\hline SJ & $\{1\}$ & $\{2\}$ & $\{3\}$ \\
& 35.90 & 33.16 & 26.84 \\
\hline 1 - Guard & & .346 & $\mathbf{. 0 0 7}$ \\
2 - Point forward & .346 & & $\mathbf{. 0 4 3}$ \\
3 - Center & $\mathbf{. 0 0 7}$ & $\mathbf{. 0 4 3}$ & \\
CMJ & $\{1\}$ & $\{2\}$ & $\{3\}$ \\
& 37.80 & 35.44 & 31.06 \\
1 - Guard & & .348 & $\mathbf{. 0 1 6}$ \\
2 - Point forward & .348 & & .095 \\
3 - Center & $\mathbf{. 0 1 6}$ & .095 & \\
OL CMJ & $\{\mathbf{1}\}$ & $\{2\}$ & $\{3\}$ \\
& $\mathbf{2 1 . 8 0}$ & 18.32 & 16.58 \\
1 - Guard & & .022 & .002 \\
2 - Point forward & $\mathbf{. 0 2 2}$ & & .214 \\
3 - Center & $\mathbf{. 0 0 2}$ & .214 & \\
DJ & $\{\mathbf{1}\}$ & $\{2\}$ & $\{3\}$ \\
& $\mathbf{4 6 . 3 4}$ & 43.02 & 38.82 \\
1 - Guard & & .284 & $\mathbf{. 0 2 6}$ \\
2 - Point forward & .284 & & .182 \\
3 - Center & $\mathbf{. 0 2 6}$ & .182 & \\
\hline
\end{tabular}

\section{DISCUSSION}

The goal of contemporary top basketball is for each player to possess the ability to move effectively irrespective of their position on the team, and to possess a high level of physical fitness (Ademović, 2016). However, the various positions on the team determine the requirements of specific forms of movement and the especially large number of technical-tactical elements such as driving the ball (Verstegen \& Marčelo, 2010). Most of the tasks in the game are performed in a relatively small space, where rapid changes in direction and explosivity have a deciding impact on success (Kocić, 2007), which the results of this research have confirmed. It is precisely the extent of preparedness of the players that determines the possibility of meeting all the requirements during a game, and performing all the movements which lie at the basis of the motor skill of agility (Forlan, 2010), while the results of this research have indicated that the difference is greatest between the guard and center position (Table 2). During a single basketball game, the players change the form or intensity of movement on average every 2 s (Jakovljević et al., 2011), but players also makes between 53 to 157 highly intense movements along a straight trajectory with an average duration of $1.7 \mathrm{~s}$, while they spend $60 \%$ of the time moving with low, and $15 \%$ with very high intensity (Zarić, 2014). A combination of physical and technical-tactical abilities is a precondition for a basketball player to achieve significant results on tests for the evaluation of agility and explosive power. On average, during a game, basketball players change direction every 1-3sec (Matthew \& Delextrat, 2009; Scanlan et al., 2011; Stojanović, Ristić, McMaster, \& Milanović, 2017) and they have 50-60 changes in speed and direction (McInnes, Carlson, Jones, \& McKenna, 1995; Balčiūnas, Stonkus, Abrantes, \& Sampaio, 2006). Rapid changes in direction of high intensity encompass 8.8\%, $5.3 \%$, and $2.1 \%$ of the overall game time (Abdelkrim, El Fazaa, \& El Ati, 2007), while 
Conte et al. (2015) point out that rapid changes in direction make up 20,7\% of the overall activity in the game. Considering that these indicators are to a greatest extent a feature of guards, the results of this research support this claim. All of the aforementioned indicates the great prevalence of changes in direction and activities of the agility type. Numerous studies have confirmed that explosive power in the form of vertical jumps is a significant ability of elite basketball players (Latin, Berg, \& Baechle, 1994; Hoffman, Tenenbaum, Maresh, \& Kraemer, 1996; Ziv \& Lidor, 2009). The players who play the position of center and forward, and often guards as well, perform $46 \pm 12$ jumps during a game (Mclennes et al., 1995; Castagna, Chaouachi, Rampinini, Chamari \& Impellizzeri, 2009). Viewed as a part of offence and defense, guards are tasked with greater requirements for explosive movement (Abdelkrim et al., 2007; Abdelkrim, Chaouachi, Chamari, Chtara, \& Castagna, 2010; Köklü, Alemdaroğlu, Koçak, Erol, \& Findıkoğlu, 2011) compared to forward and center players, which has been confirmed by the results of this research (Table 4). Basketball is a game of agility and explosive movement, and constant alterations between defense and offence, including a greater number of jumps upward and to the side. The requirements of elite basketball are such that players use precisely their predispositions to avoid defensive players and shoot at the basket or pass the ball to a free team-mate. There is almost no activity in basketball in which there is no agility or explosive power, and so the conclusion is that their improvement will help player improve their sports achievements and the possibility of neutralizing their opponents (Kocić, 2005; Nikolić, 2016). The knowledge that coaches acquire regarding the significance of agility and explosive power of basketball players in relation to their positions on the team is relevant for the successful planning and programming of training sessions, the selection and application of methods, and the realization of the desired effects of the training process (Aksović \& Berić, 2017). Thus, the results of this research have confirmed the existence of differences regarding the position of the players on the team (Table 1 and Table 3). The development of agility and explosive power should be adapted and specialized to suit each particular position on the team (Kocić \& Berić, 2015), due to the specific tasks and goals required during a basketball game.

\section{CONCLUSION}

The results of this research have indicated that there is a difference between basketball players who compete at the national level in agility, based on their position on the team, and that this difference was greatest between the guard and center positions, while the difference between the guard and forward positions is close to statistical significance. Furthermore, when it comes to explosive power the results have indicated that there are differences and they are greatest between the guard and forward positions and guard and center positions, but that there was also a difference between the point forward and center positions, but only for the variable of the squat jump. This research has determined the state and level of motor skills of agility and explosive power of the players in relation to their position on the team, and based on that we can construct a model of players in relation to their position on the team and the possibility of comparing it with corresponding samples, with the aim of proper programming and planning of training. Experts in the field of basketball require exercises which will in the shortest period of time possible contribute to the improvement of agility and explosive power, as the abilities which are of importance for success in basketball. 


\section{REFERENCES}

Abdelkrim, N.B., El Fazaa, S., \& El Ati, J. (2007). Time-motion analysis and physiological data of elite under19-year-old basketball players during competition. British Journal of Sports Medicine, 41(2), 69-75.

Abdelkrim, N. B., Chaouachi, A., Chamari, K., Chtara, M., \& Castagna, C. (2010). Positional role and competitive-level differences in elite-level men's basketball players. The Journal of Strength \& Conditioning Research, 24(5), 1346-1355.

Ademović, I., Milenković, D. \& Kocić, M. (2014). Agilnost i eksplozivna snaga nogu vertikalnog tipa u vrhunskoj košarci (Agility and explosive leg strength of vertical type in elite basketball). In I. Gajić (Ed.). Proceedings of the 1st International Conference "Sport, Healt, Environment", (pp. 37-44). Belgrade: Faculty for Sport, University "Union-Nikola Tesla". In Serbian

Ademović, I. (2016). Brzinsko-eksplozivna svojstva vrhunskih košarkaša (Speed-explosive properties of elite basketball players). Unpublished Doctoral Dissertation, Niš: Faculty of Sport and Physical Education, University of Niš. In Serbian

Aksović, N., \& Berić, D. (2017). Differences in explosive power between basketball players of different age. Fizička kultura, 71(1), 36-42.

Asadi, A., \& Arazi, H. (2012). Effects of high-intensity plyometric training on dynamic balance, agility, vertical jump and sprint performance in young male basketball players. Journal of Sport and Health Research, 4(1), 35-44.

Balčiūnas, M., Stonkus, S., Abrantes, C., \& Sampaio, J. (2006). Long term effects of different training modalities on power, speed, skill and anaerobic capacity in young male basketball players. Journal of Sports Science \& Medicine, 5(1), 163-170.

Beekhuizen, K.S., Davis, M.D., Kolber, M.J., \& Cheng, M.S.S. (2009). Test-retest reliability and minimal detectable change of the hexagon agility test. The Journal of Strength \& Conditioning Research, 23(7), 2167-2171.

Bosco, C., Luhtanen, P., \& Komi, P.V. (1983). A simple method for measurement of mechanical power in jumping. European Journal of Applied Physiology, 50, 273-282.

Castagna, C., Chaouachi, A., Rampinini, E., Chamari, K., \& Impellizzeri, F. (2009). Aerobic and explosive power performance of elite Italian regional-level basketball players. The Journal of Strength \& Conditioning Research, 23(7), 1982-1987.

Conte, D., Favero, T.G., Lupo, C., Francioni, F.M., Capranica, L., \& Tessitore, A. (2015). Time-motion analysis of Italian elite women's basketball games: Individual and team analyses. The Journal of Strength \& Conditioning Research, 29(1), 144-150.

Delextrat, A. \& Cohen, D. (2009). Strength, power, speed, and agility of women basketball players according to playing position. Journal of Strength and Conditioning Research, 23(7), 1974-1981.

Forlan, B. (2010). Integrisanje sport-specifičnih motornih znanja u kondicionom treningu. In B. Forlan (Ed.), Vrhunski kondicioni trening (Top fitness training), (pp. 217-268). Belgrade: Data Status. In Serbian.

Getchell, B. (1979). Physical fitness: A way of life. New York: John Wiley.

Hoffman, J.R., Tenenbaum, G., Maresh, C.M., \& Kraemer, W.J. (1996). Relationship between athletic performance tests and playing time in elite college basketball players. The Journal of Strength \& Conditioning Research, 10(2), 67-71.

Issurin, V.B. (2008). Block periodization 2: Fundamental concepts and training design. Ultimate Athlete Concepts.

Jakovljević, S., Karalejić, M., Pajić, Z., \& Mandić, R. (2011). Ubrzanje i brzina promene smera i načina kretanja kvalitetnih košarkaša (Acceleration and speed of change of direction and movement of quality basketball players). Fizička kultura, 65(1), 16-23. In Serbian

Jamurtas, A.Z., Fatouros, I.G., Buckenmeyer, P., Kokkinidis, E., Taxildaris, K., Kambas, A., et al. (2000). Effects of plyometric exercise on muscle soreness and plasma creatine kinase levels and its comparison with eccentric and concentric exercise. The Journal of Strength \& Conditioning Research, 14(1), 68-74.

Kocić, M. (2005). Razlike u motoričkim, situaciono-motoričkim i funkcionalnim sposobnostima košarkaša različitog ranga takmičenja (Differences in motor, situational-motor skills and functional abilities of basketball players of different ranking competitions). Master Thesis. Niš: Faculty of Sport and Physical Education, University of Niš. In Serbian

Kocić, M. (2007). Uticaj programiranog trenažnog procesa na razvoj motoričkih i situaciono - motoričkih sposobnosti mladih košarkaša (The influence of the programmed training process on the development of motor and situational - motor skills of young basketball players). Unpublished Doctoral Dissertation, Niš: Faculty of Sport and Physical Education, University of Niš. In Serbian 
Kocić, M., \& Berić, D. (2015). Košarka (Basketball). Niš: Faculty of Sport and Physical Education, University of Niš. In Serbian

Kocić, M., Berić, D., Radovanović, D., \& Simović, S. (2012). Differences in mobility, situational, motor and functional abilities of basketball players at different levels of competition. Facta Universitatis Series Physical Education and Sport, 10(1), 23-32.

Kraemer, W.J., \& Gomez, A.L. (2010). Osnove razvoja fizičke forme (Fundamentals of the development of physical fitness). In B. Forlan (Ed.), Vrhunski kondicioni trening (Top fitness training), (pp. 3-17). Belgrade: Data Status. In Serbian

Köklü, Y., Alemdaroğlu, U., Koçak, F., Erol, A., \& Fındıkoğlu, G. (2011). Comparison of chosen physical fitness characteristics of Turkish professional basketball players by division and playing position. Journal of Human Kinetics, 30, 99-106.

Latin, R.W., Berg, K., \& Baechle, T. (1994). Physical and performance characteristics of NCAA Division I male basketball players. The Journal of Strength \& Conditioning Research, 8(4), 214-218.

Lehnert, M., Hůlka, K., Malý, T., Fohler, J., \& Zahálka, F. (2013). The effects of a 6-week plyometric training programme on explosive strength and agility in professional basketball players. Acta Gymnica, 43 (4), 7-15.

Manojlović, V., \& Erčulj, F. (2013). Impact of the focus of attention on vertical jump performance of junior basketball players. Fizička kultura, 67(1), 61-67.

Matthew, D., \& Delextrat, A. (2009). Heart rate, blood lactate concentration, and time-motion analysis of female basketball players during competition. Journal of Sports Sciences, 27(8), 813-821.

McInnes, S.E., Carlson, J.S., Jones, C.J., \& McKenna, M.J. (1995). The physiological load imposed on basketball players during competition. Journal of Sports Sciences, 13(5), 387-397.

Metaxas, T.I., Koutlianos, N., Sendelides, T., \& Mandroukas, A. (2009). Preseason physiological profile of soccer and basketball players in different divisions. The Journal of Strength and Conditioning Research, 23(6), 1704-1713.

Morsal, B., Shahnavazi, A., Ahmadi, A., Zamani, N., Tayebisani, M., \& Rohani, A. (2014). Effects of polymeric training on explosive power in young male basketball. European Journal of Experimental Biology, 4(3), 437-439.

Nikolić, D. (2016). Kompleksni trening mladih košarkaša (Complex training of young basketball players). Unpublished Doctoral Dissertation, Niš: Faculty of Sport and Physical Education, University of Niš. In Serbian

Ostojić, S.M., Mazić, S., \& Dikić, N. (2006). Profiling in basketball: Physical and physiological characteristics of elite players. The Journal of Strength and Conditioning Research, 20(4), 740

Pauole, K., Madole, K., Garhammer, J., Lacourse, M., \& Rozenek, R. (2000). Reliability and validity of the T-test as a measure of agility, leg power, and leg speed in college-aged men and women. The Journal of Strength \& Conditioning Research, 14(4), 443-450.

Popović, S., Smajić, M., Molnar, S., \& Mašanović, B. (2009). Determinisanost telesne kompozicije vrhunskih sportista (Determining body composition of top level athletes). Teme, 4, 1535-1549. In Serbian

Scanlan, A.T., Tucker, P.S., \& Dalbo, V.J. (2014). A comparison of linear speed, closed-skill agility, and openskill agility qualities between backcourt and frontcourt adult semiprofessional male basketball players. The Journal of Strength \& Conditioning Research, 28(5), 1319-1327.

Sigmon, C. (2005). Agility drills. FIBA Assist Magazine, 6(17), 59-63.

Stojanović, E., Aksović, N., Stojiljković, N., Stanković, R., Scanlan, A.T., \& Milanović, Z. (2018). Reliability, usefulness, and factorial validity of change-of-direction speed tests in adolescent basketball players. The Journal of Strength \& Conditioning Research. DOI: 10.1519/JSC.0000000000002666

Stojanović, E., Ristić, V., McMaster, D.T., \& Milanović, Z. (2017). Effect of plyometric training on vertical jump performance in female athletes: A systematic review and meta-analysis. Sports Medicine, 47(5), 975-986.

Trunić, N. (2007). Trening mladih košarkaša različitih uzrasnih kategorija (Training of young basketball players of different age categories). Belgrade: High School for Sport: DTA. In Serbian

Verstegen, M., \& Marčelo, B. (2010). Agilnost i koordinacija (Agility and coordination). In B. Forlan (Ed.), Vrhunski kondicioni trening (Top fitness training), (pp. 141-167). Belgrade: Data Status. In Serbian

Young, W.B., Dawson, B., \& Henry, G.J. (2015). Agility and change-of-direction speed are independent skills: Implications for training for agility in invasion sports. International Journal of Sports Science and Coaching, 10(1), 159-169.

Zhang, X. (2013). Research of jumping ability and explosive power based on plyometric training. Lecture Notes in Electrical Engineering, 206, 427-433.

Ziv, G., \& Lidor, R. (2009). Vertical jump in female and male basketball players-review of observational and experimental studies. Journal of Science and Medicine in Sport, 13(3), 332-339.

Zarić, I. (2014). Efekti šestonedeljnog trenažnog procesa na motoričke i funkcionalne sposobnosti košarkašica (The effects of the six-week training process on the motor and functional abilities of female basketball players). Fizička kultura, 68 (1), 75-82. In Serbian 


\section{RAZLIKE U AGILNOSTI I EKSPLOZIVNOJ SNAZI KOŠARKAŠA U ODNOSU NA IGRAČKE POZICIJE U TIMU}

Košarka je sportska igra $i$ ista se sastoji od brzih promena pravca kretanja, naglih zaustavljanja $i$ polaska u dribling $i$ velikog broja skokova. Različite pozicije igrača u igri upravo određuju zahteve specifičnih formi kretanja, iako savremena košarkaška igra teži da igrači na svim pozicijama poseduju pomenute sposobnosti. Na uzorku od 15 košarkaša, podeljenih u tri grupe po pet u odnosu na pozicije u timu, $i$ to (bekovi, krila i centri) utvrđivane su razlike u agilnosti (Agility T Test, Hexagon Agility Test, Illinois Agility Test i Lane Agility Drill) i eksplozivnoj snazi (Squat jump, Countermovement Jump, Drop Jump i One-legged Counter Movement Jump). Za utvrđivanje razlika između košarkaša u odnosu na igračke pozicije u timu primenjena je ANOVA analiza za nezavisne uzorke i naknadna Post hok analiza. Rezultati istraživanja su pokazali da razlika postoji između bekova u odnosu na krila $i$ centre.

Ključne reči: košarkaši, agilnost, eksplozivna snaga, igračke pozicije, razlike. 